\title{
Research on Practical Teaching Reform of Undergraduate Talents Training in Application- oriented Financial Management Major*
}

\author{
Na Wang \\ Harbin Institute of Finance \\ Harbin, China
}

\begin{abstract}
The core task of higher education is to improve the quality of talent cultivation and the deepening of education and teaching reform can promote the development of higher education in the new era. Under the background of supply-side reform and industrial transformation and upgrading in China, the cultivation of comprehensive quality of talents and sustainable development has become particularly important. Taking the course of "Enterprise Financial Analysis" as an example, this paper introduces the practical content and the innovative point of the course reform, discusses the reform of the teaching system of the practical course of the financial management major in the application-oriented undergraduate colleges, and points out that the innovation of the practical teaching is beneficial to the cultivation of the applied talents with strong practical ability.
\end{abstract}

Keywords-enterprise financial analysis; course reform; practice; research

\section{INTRODUCTION}

The rapid development of the Internet has greatly promoted the innovation and development of modern education. The Internet creates an open data platform, which provides a great deal of economic information for teaching. In the teaching and learning of enterprise financial analysis, teachers and students can make use of the unique advantages of the Internet to introduce a large number of economic data information into the classroom, such as the annual financial reporting information of listed companies, macroeconomic statistics information, national policy information, business development information, and so on, thus solving the problem of limited information in teaching materials and backward education information. This paper mainly studies the teaching reform of the course of enterprise financial analysis based on the Internet, in order to seek an effective practical teaching mode, and thus cultivate the applied financial management professionals with strong practical operation ability.

*This paper is the phased research results of key project of higher education reform in Heilongiiang Province: "Research and Practice of Integrated Practical Teaching System Optimization in Universities of Finance and Economics Transformation-Taking Financial Management Major as an Example". Project number: SJGZ20170028

\section{THE TEACHING OBJECT AND ENVIRONMENT OF THE COURSE "ENTERPRISE FINANCIAL ANALYSIS"}

\section{A. Teaching Object}

Enterprise financial analysis course is a major compulsory course for financial management undergraduate students, with 54 total class hours, of which 24 hours is theoretical teaching hours, and 30 hours is for practical teaching. Its prerequisite courses include financial management, management, accounting, and statistics and so on. Students take two forms of classes: one is single class, with no more than 30 people in each class; the other is merger class of 60-90 students.

\section{B. Objective of Course Reform}

The objective of this course reform is to enhance students' proactivity in learning by introducing practical teaching, make them master the skills of financial analysis by active learning, combine theory with practice closely, and finally be able to make a complete financial analysis report according to the financial statement information.

Before the reform, the teaching process of the course Enterprise Financial Analysis is dominated by teachers. In the process of theoretical course teaching, exercises and cases are used to help students absorb and digest the content of the course. The final examination adopts the form of closed-book exam, and the types of questions are choice, judgment, calculation, and case analysis and so on. The teaching process of the course Enterprise Financial Analysis after the reform is guided by the teachers, who first impart the theoretical knowledge to the students, and then integrate the theory with the practical application by arranging the tasks - students finishing the tasks - students commenting on each other-teachers commenting - students improving. The final grade consists of a combination of tasks throughout the semester, and is converted into grades of distinction, merit, medium, pass, and fail.

\section{Teaching Environment and Equipment}

The teaching environment and facilities include the Internet, multimedia classrooms, computers and mobile phones. With the help of the Internet, students can inquire 
the macro-economic information, enterprise financial data, enterprise management information and download materials and so on when making enterprise finance analysis. The multimedia classroom is used for teachers' teaching, students' discussion and presentation of students' analysis. The computer can be used for statistical analysis of financial statement data and calculation of indicators; Mobile phones can help students to store course information in the classroom, quickly inquire economic information, and conveniently communicate with group.

\section{PRACTICAL CONTENTS OF THE COURSE REFORM OF ENTERPRISE FINANCIAL ANALYSIS}

The theory teaching and practice teaching of enterprise financial analysis course are interlaced. The practice teaching includes the practice of compiling accounting statement and the practice of financial analysis of accounting report. The accounting statement compiling requires 4 hours while the practice of financial analysis of listed companies needs 26 hours.

\section{A. Practical Training of Accounting Statement Compiling}

1) Purpose of practical training: Accounting statement, mainly including balance sheet, profit statement, cash flow statement, and statement of change in equity, is an important basis for enterprise financial analysis. Students need to be familiar with the relevant knowledge of accounting statement and skillfully grasp the compilation method of accounting statement before learning the technology of enterprise financial analysis. Through the practice training of financial statement compiling, the theoretical knowledge of students' financial statement preparation is consolidated, their understanding of financial statement is deepened, and the structure of financial statement and the relationship between them are clarified.

2) Organization of practical training: First of all, 4-6 students are divided into a study group. One group leader is selected to take charge of the work in the group, and the students discuss, study and practice in group. Then the work plan and task is determined and each group prepares a work plan, to complete the accounting statements compiling.

3) Practical training materials: The training uses the information publicly disclosed by Coastal Corporation in 2015 on the Internet, including

- Account balance sheet of Coastal Corporation on 1 January 2015.

- All business transaction of Coastal Corporation in 2015.

- Accounting entry compiled according to all business transaction of Coastal Corporation in 2015.

4) Task of practical training:

- Developing a work plan for practical training of financial and accounting statements compiling.
- Compiling the financial statements of Coastal Corporation for 20xxx year according to the information given.

- Completing the work summary of practical training of financial statement compiling.

5) Operational procedures for practical training:

- Each group discusses and makes the practical training work plan for financial statements compiling.

- Instructor reviews the work plan of each group and signs and approves it.

- Each group completes the financial accounting statement of Coastal Corporation in 20xxx year according to the task and the practical training worksheet.

- Each group completes the summary of practical training work of financial statements compiling.

- Teachers summarize and give comprehensive guidance.

\section{B. Practical Training of Financial Analysis}

The practical training of financial analysis includes the analysis of the balance sheet of the listed company, profit statement, cash flow statement, statement of change in equity, notes to financial statements, debt paying ability, profitability, operational capability, development capability, and comprehensive analysis of financial and accounting report, analysis of trend and forecast, and writing of financial analysis report.

1) Purpose of practical training: Through practical operation, the theoretical knowledge learned is consolidated, various analytical methods are summed up and students' analytical ability of report forms is improved. The sense of team cooperation is strengthened through group activities, the ability of professional judgment, language communication and analysis report writing is improved.

2) Requirement for practical training:

- The groups are proficient in using the Internet and other media to consult the required information.

- They are able to use a wide range of computing tools.

- They can better use information disclosed in financial accounting reports.

- They are able to grasp the key points of all kinds of report analysis and all kinds of index calculation and analysis.

- They are able to make an objective and comprehensive analysis and evaluation of the company's financial position and operating results.

- They have the ability to compile financial analysis reports. 
- Students with outstanding performance are required to make trend analysis and forecast analysis of the financial statements of listed companies.

3) Organization of practical training: It is the same as that of accounting statement compiling.

4) Materials for practical training: Annual financial report, audit report, asset appraisal report and industry information of different listed companies in recent three years.

5) Task of practical training:

- Developing the work plan.

- Collecting the annual financial reports of different listed companies in recent three years and printing the accounting statement to submit them to the instructors for verification.

- Getting familiar with financial report, audit report, asset evaluation report of the company to be analyzed.
- Completing the calculation of the analytical statement step by step.

- Drawing the statistical analysis figure.

- Producing analysis reports of balance sheet, profit statement and cash flow statement.

- Presenting the phased results of analysis, group reviews, and teacher reviews.

- Comparatively analyzing industry indicators.

- Comprehensively analyzing and evaluating the performance of listed companies to compile comprehensive analysis reports.

- Producing PPT and presenting results; using statistical method to analyze and forecast the trend.

6) Operational procedures for practical training

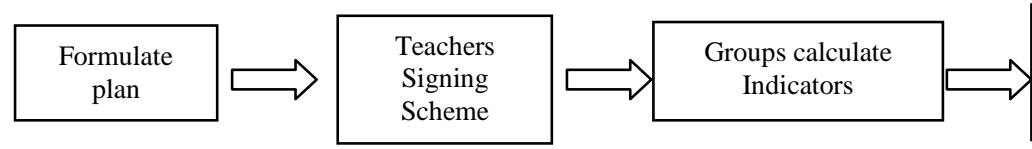

7) Work order of practical training

- Work plans for practical training in various types of analysis.

- Various types of trend analysis tables, structure analysis tables and vertical analysis tables.

- Comparative analysis of various indicators.

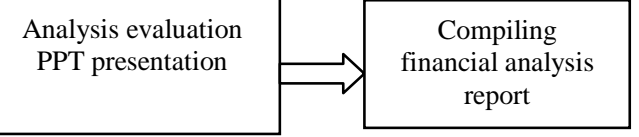

- Analysis reports of various types of statement and comprehensive financial analysis reports.

- Comparative analysis statement of industry indicators.

\section{Evaluation Criteria of Final Grade}

TABLE I. FINAL GRADE COMPOSITION OF ENTERPRISE FINANCIAL ANALYSIS COURSE

\begin{tabular}{|c|c|c|c|c|c|c|}
\hline full mark & $\begin{array}{c}\text { attendance } \\
\text { classroom performance }\end{array}$ & classroom notes & $\begin{array}{c}\text { homework } \\
\text { (twice) }\end{array}$ & midterm test & PPT presentation & financial analysis report \\
\hline 100 points & 30 points & 10 points & 10 points & 10 points & 10 points & 30 points \\
\hline
\end{tabular}

TABLE II. STUDENTS' FINAL RESUlts

\begin{tabular}{|c|c|c|c|c|c|c|c|c|c|c|c|c|c|}
\hline $\begin{array}{c}\text { financial } \\
\text { management } \\
\text { class } 1\end{array}$ & $\begin{array}{c}\text { family } \\
\text { name } \\
\text { first } \\
\text { name }\end{array}$ & $\begin{array}{l}\text { student } \\
\text { number }\end{array}$ & $\begin{array}{c}\text { analysis } \\
\text { company }\end{array}$ & $\begin{array}{c}\text { score of } \\
\text { financial } \\
\text { analysis } \\
\text { report }\end{array}$ & $\begin{array}{c}\text { PPT } \\
\text { points }\end{array}$ & $\begin{array}{c}\text { notes } \\
1\end{array}$ & $\begin{array}{c}\text { notes } \\
2\end{array}$ & $\begin{array}{c}\text { homework } \\
1\end{array}$ & $\begin{array}{c}\text { homework } \\
2\end{array}$ & $\begin{array}{c}\text { test } \\
\text { score }\end{array}$ & $\begin{array}{c}\text { attendance } \\
\text { classroom } \\
\text { performance }\end{array}$ & $\begin{array}{l}\text { total } \\
\text { score }\end{array}$ & $\begin{array}{l}\text { final } \\
\text { score }\end{array}$ \\
\hline \multirow{4}{*}{ A1 group } & first & 36 & \multirow{4}{*}{$\begin{array}{l}\text { Shenzhen } \\
\text { Chiwan } \\
\text { harbor } \\
\text { airlines } \\
\text { co. LTD. }\end{array}$} & 24 & 8 & 3 & 5 & 5 & 5 & 10 & 30 & 90 & distinction \\
\hline & second & 38 & & 20 & 8 & 3 & 5 & 5 & 5 & 10 & 30 & 86 & merit \\
\hline & third & 10 & & 22 & 8 & 5 & 5 & 5 & 5 & 10 & 30 & 90 & distinction \\
\hline & forth & 29 & & 20 & 8 & 5 & 0 & 5 & 5 & 10 & 28 & 81 & merit \\
\hline
\end{tabular}

\section{INNOVATIONS IN COURSE REFORM}

- A student-centered teaching model has been formed. In the teaching process, the role of teachers is to guide, answer, comment and summarize. As the main body, students do more, ask more, speak more, and analyze more.

- It is beneficial for students to integrate the knowledge of many courses. In the practical teaching and learning of the course Enterprise Financial Analysis, students need to use the related knowledge of management, accounting, and statistics comprehensively to enhance their ability to integrate knowledge.

- The content of homework and the form of examination are innovated. The course of "Enterprise Financial Analysis" requires different homework contents for each student, which can cultivate students' ability to think independently and analyze problems. Students can choose the content of homework according to their own interests in a certain range, which changes the same content of homework in the past and avoid plagiarism. For example, in the collection of information on listed companies, some students choose the leading 
enterprises in their hometown, while some students choose the enterprises where they intend to be employed in future as shown in "Table I" and "Table II".

- Integrating web-based knowledge into classroom teaching. A large number of statistical data and case information in the Internet effectively make up for the lack of time lag of knowledge point in the textbooks.

- Enhancing the coherence of knowledge points in the teaching content.

- The tasks assigned by the teachers are connected and have the characteristics of continuity and progression. Students can't start the next task until they have done a good job in this task. The last completed task is financial analysis report compiling, which is an analysis and summary of all tasks.

\section{CONCLUSION}

The practice teaching reform of the course Enterprise Financial Analysis has gone through the stages of exploration-practice-summing up experienceimprovement. At present, it has been implemented for four semesters, and the teaching design of the course is becoming maturer and maturer. The reform of practical teaching has deepened the teaching thought of teaching students according to their aptitude and improved the students' practical operation ability. In the process of students' accomplishing tasks, teachers have enough time to observe the students to know the degree of their mastery of knowledge. For the students who have completed the tasks quickly and well, the teachers can increase the tasks appropriately; for students who have difficulty in accomplishing their tasks, teachers can increase the time available for guidance; for problems that most of the students have in common, teachers can explain uniformly. At the same time, the close combination of learning and use improves the students' interest and confidence in learning. For example, combining with the data of listed companies and using the calculation method of industry average index, students can easily calculate the average asset-liability ratio of the pharmaceutical industry as a reference index for analyzing the asset-liability ratio of pharmaceutical enterprises. The reformed practical teaching also helps to cultivate the students' innovative spirit. In practical operation, students can draw inferences about other cases from one instance. For example, by studying the calculation of the vertical analysis of the balance sheet, students can independently complete the calculation of the vertical analysis of the profit statement and the cash flow statement. In addition, students can find out more effective analysis methods in practice. For example, according to the theoretical knowledge learned, students can freely choose and combine the calculation methods by combining with the actual enterprise. On the whole, we can see that innovative practical teaching is beneficial to cultivate applied talents with stronger practical ability. Due to individual differences of students, some students will spend a lot of time in the process of completing the task. In addition, how to improve the students' processing ability and learning efficiency of online information still needs teachers to put forward feasible countermeasures and improve them in the future teaching.

\section{REFERENCES}

[1] Yu Xinjie. Student-centered Teaching and Learning-The Practice of complementing flipped classroom with MOOC Resources [M]. Beijing: Higher Education Press, 2015.125

[2] Zhang Xianzhi, Chen Youbang. Financial Analysis [M]. Dalian: Northeast University of Finance and Economics Press, 2014.

[3] Pei Shuqin. Exercises and Practical training of Financial Accounting Report Analysis [M]. Beijing: Beijing Normal University Press, 2011.36-39, 48-50.

[4] Wang Na. On application of task-driven method in management teaching [J]. Business China, 2012, 9: 397. 